NOTE

\title{
Mean temperature of the catch increases quickly in the Mediterranean Sea
}

\author{
Athanassios C. Tsikliras ${ }^{1, *}$, Konstantinos I. Stergiou ${ }^{1,2}$ \\ ${ }^{1}$ Laboratory of Ichthyology, Department of Zoology, School of Biology, Aristotle University of Thessaloniki, UP Box 134 \\ 54124 Thessaloniki, Greece \\ ${ }^{2}$ Institute of Marine Biological Resources and Inland Waters, Hellenic Centre for Marine Research, Aghios Kosmas, \\ 16604 Athens, Greece
}

\begin{abstract}
The mean temperature of the catch (MTC) is an indicator that has been recently proposed in order to assess the effect of global warming on the exploited marine communities. In this study, we applied the MTC to the catches from the western, central, and eastern Mediterranean Sea for the period 1970 to 2010. We found that the MTC of Mediterranean subareas has been increasing at higher rates compared to those previously reported and its increase is strongly related to sea warming. The rate of MTC increase varied among subareas $\left(0.56,1.05\right.$, and $0.29^{\circ} \mathrm{C}$ per decade for western, central and eastern Mediterranean subareas, respectively) and could have been higher had Lessepsian species, i.e. species of Indo-Pacific origin migrating through the Suez Canal, been included in the analysis (their catches are not yet officially recorded). The MTC rates we detected are higher than those previously reported for the Mediterranean as a whole. Our results indicate that, in the Mediterranean, the ratio of thermophilous to psychrophilous marine species has been changing in favour of the former, indicating either an increase in their relative proportion in the catches or a decrease in the relative proportion of the psychrophilous species. Both conditions indicate that global warming has a strong effect on marine exploited communities.
\end{abstract}

KEY WORDS: Marine fishes $\cdot$ Sea warming $\cdot$ Climate change $\cdot$ Mediterranean Sea Resale or republication not permitted without written consent of the publisher

\section{INTRODUCTION}

Historically, it is clear that overfishing has caused severe biomass declines in several fish stocks (Stergiou 2002, Pauly et al. 2003, Myers \& Worm 2003) and alterations to their population structure, including their maximum body length (Pauly et al. 1998) and size at maturity (Olsen et al. 2004). Additional impact on marine populations is derived from largescale climatic phenomena (El Niño: Bakun \& Broad 2003; North Atlantic Oscillation: Ottersen et al. 2001; Atlantic Multidecadal Oscillation: Alheit et al. 2014) and global warming, which is blamed for sea temper- ature increase (Levitus et al. 2000; for the Mediterranean Sea see Bethoux \& Gentili 1999). An increase in sea temperature may affect fish growth (Brander 1995), spawning period (Tsikliras et al. 2010) size at maturity (Tsikliras \& Stergiou 2014), and hence, recruitment and mortality, while at the same time it alters the distribution and biomass of marine populations (Cheung et al. 2010) and community structure (Stenseth et al. 2002).

In the Mediterranean Sea, the effect of sea warming is evident on the marine faunal composition (Katsanevakis et al. 2013), which has been altered by the presence of alien species of Indo-Pacific origin that 
have migrated through the Suez Canal (Lessepsian immigrants) (Golani et al. 2002). The invasion of these species has been facilitated by, among other factors, the sea warming (Galil 2008). Some of the invaders (e.g. dusky spinefoot Siganus luridus and red-eye round herring Etrumeus sadina) have established viable populations and are being commercially exploited, but their catches are not included in the database statistics of the Food and Agricultural Organization (FAO) and General Fisheries Commission for the Mediterranean (GFCM).

The mean temperature of the catch (MTC) is an index that has been recently proposed for the evaluation of the effect of sea temperature increase on marine fisheries catches (Cheung et al. 2013). MTC depends on the preferred temperature range of the species participating in the catches as it emerges from each species' global distribution (Cheung et al. 2013). Cheung et al. (2013) used the FAO landings database for 1970 to 2010 and found that MTC increased in most large marine ecosystems, including the FAO subarea 37, i.e. the Mediterranean and Black Sea combined. In a preliminary analysis, Tsikliras \& Stergiou (2013) also detected this trend in the Greek Seas.

The objective of the present work was to examine the effect of sea temperature increase on the catch composition of 3 subareas (western, central, eastern) of the Mediterranean Sea using the MTC approach.

\section{MATERIALS AND METHODS}

The annual catches (t) for the fish, crustacean and cephalopod species of the western, central, and eastern Mediterranean Sea were extracted from the GFCM database of FAO using the FishSTAT J programme (FAO 2013). These catches are available for the period 1970 to 2010 .

The preferred temperature (median, 25th and 75th percentile) were acquired from the list in Cheung et al. (2013), which covers 1700 records out of the 2635 records included in the GFCM database. The covered records represent the vast majority $(78 \%)$ of Mediterranean Sea catches $(714000 \mathrm{t}$ out of $921000 \mathrm{t}$ caught in 2010). Species aggregated at higher taxonomic level (e.g. Osteichthyes, Crustacea) in the GFCM database were excluded from the analysis.

The mean temperature of the catch (MTC) was calculated annually for 1493 records based on the median temperature preference of each species that was weighted by its catch, according to the following formula (Cheung et al. 2013):

$$
\mathrm{MTC}_{Y r}=\frac{\sum_{i}^{n} T_{i} C_{i, y r}}{\sum_{i}^{n} C_{i, y r}}
$$

where $C_{i, y r}$ are the catches of species $i$ in the Mediterranean subarea for year $y r_{,} T_{i}$ is the median temperature preference of species $i$ and $n$ is the total number of species in the annual catch.

The MTC was then correlated with the annual mean temperature anomaly $\left({ }^{\circ} \mathrm{C}\right)$ that was extracted from the global mapping routine of the National Oceanographic and Atmospheric Administration (NOAA, www.noaa.gov) for the western $\left(39.3^{\circ} \mathrm{N}\right.$, $\left.3.8^{\circ} \mathrm{E}\right)$, central $\left(37.3^{\circ} \mathrm{N}, 17.5^{\circ} \mathrm{E}\right)$ and eastern $\left(33.7^{\circ} \mathrm{N}\right.$, $\left.27.7^{\circ} \mathrm{E}\right)$ Mediterranean subareas. The Durbin-Watson statistic was used to test for temporal autocorrelation between the 2 variables.

\section{RESULTS}

The MTC increased in all areas of the Mediterranean Sea, ranging from $13.07^{\circ} \mathrm{C}$ (in 1973) to $16.89^{\circ} \mathrm{C}$ (2004) in the western Mediterranean, from $11.17^{\circ} \mathrm{C}$ (1975) to $16.55^{\circ} \mathrm{C}(2006)$ in the central Mediterranean and from $12.71^{\circ} \mathrm{C}(1975)$ to $16.57^{\circ} \mathrm{C}(2005)$ in the eastern Mediterranean (Fig. 1; black dots). The rate of increase was higher in the central Mediterranean $\left(1.05^{\circ} \mathrm{C}\right.$ per decade) compared to the western $\left(0.56^{\circ} \mathrm{C}\right.$ per decade) and eastern $\left(0.29^{\circ} \mathrm{C}\right.$ per decade $)$ areas (Fig. 1).

MTC of all Mediterranean subareas has been increasing and its increase was positively related to temperature anomalies (Fig. 1; columns). At time lag 0 , the relationship was stronger for the western (correlation coefficient $=0.66, \mathrm{p}<0.001$ ), and central (correlation coefficient $=0.77, \mathrm{p}<0.001$ ) subareas compared to the eastern Mediterranean (correlation coefficient $=0.33, p=0.033$ ). The Durbin-Watson test-statistic indicated there was autocorrelation in all areas. Autocorrelation analysis showed that the highest correlation for the western Mediterranean was observed at time lag 2 (correlation coefficient = $0.69, \mathrm{p}<0.001)$, for the central subarea at time lags 0 and 1 (correlation coefficient for both $=0.77, \mathrm{p}<$ 0.001 ) and for the eastern subarea at time lag 3 (correlation coefficient $=0.45, \mathrm{p}=0.046$ ) .

\section{DISCUSSION}

The MTC increased in all areas of the Mediterranean Sea at a quicker rate than that reported by Cheung et al. (2013) for the Mediterranean as a 


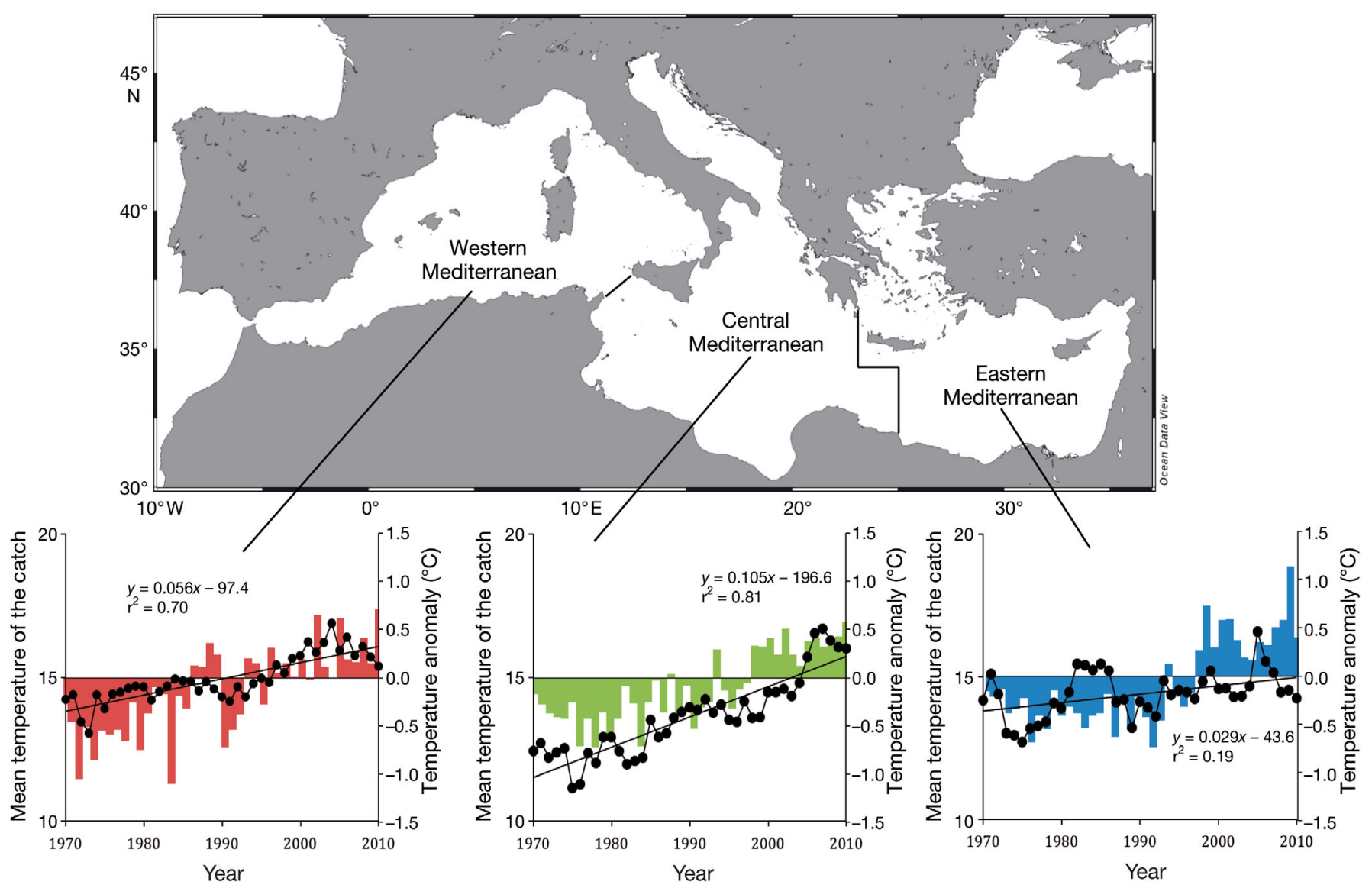

Fig. 1. The mean temperature of the catch $\left(\mathrm{MTC},{ }^{\circ} \mathrm{C}\right)$ (continuous lines, black dots) and temperature anomaly $\left({ }^{\circ} \mathrm{C}\right)$ for the western (red bars), central (green bars) and eastern (blue bars) Mediterranean Sea subareas for 1970 to 2010. Catch data were obtained from GFCM-FAO and temperature anomalies from NOAA (see 'Materials and methods')

whole $\left(0.2^{\circ} \mathrm{C}\right.$ per decade) and by Tsikliras \& Stergiou (2013) for the Greek Seas $\left(0.16^{\circ} \mathrm{C}\right.$ per decade). The MTC increase clearly indicates a change in the relative catch proportions of thermophilous (those that prefer warmer temperatures) and psychrophilous (those that prefer colder temperatures) species in favour of thermophilous species. For instance, this means that more round sardinellas Sardinella aurita (preferred temperatures ca. $25^{\circ} \mathrm{C}$ ) are caught than sardines Sardina pilchardus (preferred temperatures ca. $16^{\circ} \mathrm{C}$ ) and can be the result of either higher quantities of the thermophilous species or of lower quantities of the psychrophilous ones, or even both conditions may simultaneously hold. Regardless, the effect of sea warming on the distribution and biomass of marine populations is evident (Cheung et al. 2013). The higher rate of MTC increase in the central Mediterranean Sea is due to the higher proportion of catches from the colder Adriatic Sea (northern central Mediterranean), which had been inhabited by psychrophilous species compared to catches from the warmer Ionian Sea (southern central Mediterranean) and the lower initial MTC values (compared to the other subareas) in the early 1970s (average MTC for 1970 to 1975 was $12.25^{\circ} \mathrm{C}$ ). In contrast, the lower rate of MTC increase in the eastern Mediterranean is explained by the warmer temperatures in the area and the extended presence of thermophilous species in Levantine Sea (southern eastern Mediterranean) throughout the time-series. The time of response of the fish community to sea warming varies among subareas. Species in the central Mediterranean (timelagged by $1 \mathrm{yr}$ ) seem to respond quicker compared to the western (time-lagged by 2 yr) and the eastern (time-lagged by $3 \mathrm{yr}$ ) areas of the Mediterranean sea. The time-lag corresponds well with the rate of MTC increase which is higher in the central Mediterranean Sea, followed by the western and eastern subareas.

With only a few exceptions (e.g. Siganus spp.), the catches of Lessepsian migrants that have reached the Mediterranean Sea through Suez Canal are not yet officially recorded by the local authorities, at least not disaggregated at the species or genus level. Therefore, the contribution of the Lessepsian species 
to the total catches is masked and their effect on the community cannot be assessed through routine stock assessment methods. Hence, without the catches of alien species, the increase of MTC in the Mediterranean is solely attributed to the biomass changes of local populations. Such changes are often accompanied by distribution shifts and geographic expansions, as was the case of round sardinella Sardinella aurita (Tsikliras 2008). We predict that the incorporation of the catches of alien species in the analysis will lead to further increase of the MTC (Tsikliras \& Stergiou 2013).

Thus, the results of Cheung et al. (2013) — which analysed the Mediterranean as a whole - were confirmed for 3 Mediterranean subareas analysed individually. We suggest that the results of Cheung et al. (2013) are rather conservative (i.e. the MTC increase was probably underestimated). The change in the MTC is attributed to the Mediterranean Sea warming (Fig. 1), which facilitated the northward expansion of species with tropical and subtropical distributions. The synergistic effects of other processes, including overfishing, should be carefully examined when referring to species distributions and biomass declines.

In every hypothesis of a climatic effect on fish stock abundance or biomass, all alternative hypotheses and/or variables that could affect the biomass of the species should be examined and excluded. Therefore, MTC should be checked against the large-scale climatic phenomena of North Atlantic Oscillation and Atlantic Multidecadal Oscillation indices that have a specific periodicity and have been reported to affect some Mediterranean fish stocks (Alheit et al. 2014).

Acknowledgements. The authors thank Kenneth Sherman and 3 anonymous reviewers for their helpful comments. A.C.T. acknowledges the financial support provided by the Research Committee of Aristotle University of Thessaloniki.

\section{LITERATURE CITED}

Alheit J, Licandro P, Coombs S, Garcia A and others (2014) Atlantic Multi-decadal Oscillation (AMO) modulates dynamics of small pelagic fishes and ecosystem regime shifts in the eastern North and Central Atlantic. J Mar Syst 131:21-35

Bakun A, Broad K (2003) Environmental 'loopholes' and fish population dynamics: comparative pattern recognition

Editorial responsibility: Kenneth Sherman, Narragansett, Rhode Island, USA with focus on El Niño effects in the Pacific. Fish Oceanogr 12:458-473

Bethoux JP, Gentili B (1999) Functioning of the Mediterranean Sea: past and present changes related to freshwater input and climate changes. J Mar Syst 20:33-47

Brander KM (1995) The effect of temperature on growth of Atlantic cod (Gadus morhua L.). ICES J Mar Sci 52:1-10

Cheung WWL, Lam VWY, Sarmiento JL, Kearney K, Watson R, Zeller D, Pauly D (2010) Large-scale redistribution of maximum fisheries catch potential in the global ocean under climate change. Glob Change Biol 16:24-35

> Cheung WWL, Watson R, Pauly D (2013) Signature of ocean warming in global fisheries catch. Nature 497:365-368

FAO (2013) Fishery Information, Data and Statistics Unit GFCM capture production 1970-2010. FISHSTAT JUniversal software for fishery statistical time series, www.fao.org/fishery/statistics/software/fishstatj/en

Galil BS (2008) Alien species in the Mediterranean SeaWhich, when, where, why? Hydrobiologia 606:105-116

Golani D, Orsi-Relini L, Massuti E, Quignard JP (2002) Fishes. In: Briand F (ed) CIESM atlas of exotic species in the Mediterranean. CIESM, Monaco

Katsanevakis S, Zenetos A, Belchior C, Cardoso AC (2013) Invading European seas: assessing pathways of introduction of marine aliens. Ocean Coast Manage 76:64-74

Levitus S, Antonov JI, Boyer TP, Stephens C (2000) Warming of the world ocean. Science 287:2225-2229

> Myers RA, Worm B (2003) Rapid worldwide depletion of predatory fish communities. Nature 423:280-283

> Olsen EM, Heino M, Lilly GR, Morgan MJ, Brattey J, Ernande B, Dieckmann U (2004) Maturation trends indicative of rapid evolution preceded the collapse of northern cod. Nature 428:932-935

Ottersen G, Planque B, Belgrano A, Post E, Reid PC, Stenseth NC (2001) Ecological effects of the North Atlantic Oscillation. Oecologia 128:1-14

> Pauly D, Christensen V, Dalsgaard J, Froese R, Torres F Jr (1998) Fishing down marine food webs. Science 279:860-863

Pauly D, Alder J, Bennett E, Christensen V, Tyedmers P, Watson R (2003) The future for fisheries. Science 302: 1359-1361

Stenseth NC, Mysterud A, Ottersen G, Hurrell JW, Chan KS, Lima M (2002) Ecological effects of climate fluctuations. Science 297:1292-1296

> Stergiou KI (2002) Overfishing, tropicalization of fish stocks, uncertainty and ecosystem management: resharpening Ockham's razor. Fish Res 55:1-9

> Tsikliras AC (2008) Climate-related geographic shift and sudden population increase of a small pelagic fish (Sardinella aurita) in the eastern Mediterranean Sea. Mar Biol Res 4:477-481

Tsikliras AC, Stergiou KI (2013) Mean temperature of the catch from the Greek Seas. Proc Hell Conf Ichthyol 15: 205-208

> Tsikliras AC, Stergiou KI (2014) Size at maturity of Mediterranean marine fishes. Rev Fish Biol Fish 24:219-268

> Tsikliras AC, Antonopoulou E, Stergiou KI (2010) Spawning period of Mediterranean marine fishes. Rev Fish Biol Fish 20:499-538

Submitted: May 26, 2014; Accepted: August 18, 2014

Proofs received from author(s): November 10, 2014 